\title{
PENSION REFORM IN HUNGARY
}

\author{
P. GEDEON \\ (Received: 21 November 2000; revision received: 31 January 2001; \\ accepted: 12 February 2001)
}

\begin{abstract}
Reforms are not created simply by will, they are constrained by path dependency and also by existing economic and political structures. The course of reforms is also dependent on the formulation of reform alternatives and the balance of power among decisive actors. Both the postponement and then the introduction of the pension reform in Hungary can be explained by the economic and political constraints of the reform, by how reform alternatives were formulated, and by the role of the different actors in the reform process. The structure of this paper reflects these considerations. First, I summarize the characteristics of the socialist pension system that partly created path dependency in the process of pension reform. Second, I look at the economics of pension reform, by discussing the economic constraints of the reforms, and presenting the economic aspects of reform arguments and economic policies modifying and changing the pension system. Third, I examine the politics of the pension reform, and describe the political process of bargaining that generated reform outcomes. Finally, I deal with the role of the World Bank that was the most important international actor in the Hungarian pension reform process.
\end{abstract}

Keywords: pension reform, Hungary, political economy

JEL classification index: P26

\section{INTRODUCTION}

In Hungary, social policy reforms in general and the pension reform in particular followed the introduction of the institutions of market economy with a considerable time lag, if at all. Although it was clear from the outset that the communist welfare state ${ }^{1}$ could not be sustained, comprehensive institutional reforms in the pension or health care systems were not introduced in the first six years of the postsocialist transition. This uneasiness to reform the social security systems has

1 The communist welfare state was called as the premature welfare state by Kornai (1996a, 16).

Correspondence: P. Gedeon, Department of Comparative Economics, Budapest University of Economic Sciences and Public Administration, H-1093 Budapest, Fővám tér 8, Hungary. E-mail: pgedeon@comp.bke.hu 
to do with the contradicting constraints decision makers have to face in the process of systemic change.

There are economic constraints rooted in the transformational crisis (Kornai, 1993a, 8-29) that put the government under the pressure of partly cutting, partly restructuring welfare spending. There are political constraints rooted in the nature of democratic politics that put the government under pressure to maintain the achieved level of social services and to compensate the losers of the economic transformation, generating economic recession. In the course of implementing social policy reforms, policy makers try to make compatible the incompatible demands of market economy and political democracy. ${ }^{2}$

The nature of these dual constraints may partly explain why the radical reform of the pension system did not take place in the first period of the postsocialist transition in Hungary. It makes even more interesting the question then, why the pension reform could be carried out in the second half of the $90 \mathrm{~s}$. This is the problem I am going to address in this paper. ${ }^{3}$

Reforms are not created simply by will, they are constrained by path dependency and also by existing economic and political structures. The course of reforms is also dependent on the formulation of reform alternatives and the balance of power among decisive actors. Both the postponement and then the introduction of the pension reform can be explained by the economic and political constraints of the reform, by how reform alternatives were formulated, and by the role of the different actors in the reform process. The structure of this paper reflects these considerations. First, I summarize the characteristics of the socialist pension system that partly created path dependency in the process of pension reform. Second, I look at the economics of pension reform, by discussing the economic constraints of the reforms, and presenting the economic aspects of reform arguments and economic policies modifying and changing the pension system. Third, I examine the politics of the pension reform, and describe the political process of bargaining that generated reform outcomes. Finally, I deal with the role of the World Bank that was the most important international actor in the Hungarian pension reform process.

2 The tension between market economy and political democracy was analyzed by Offe (1990).

3 This research question was also formulated by Katharina Müller: "Pension systems have long been considered particularly difficult to reform, as they tend to create powerful clienteles. This is particularly true for PAYG systems that build up long-term expectations, being hard to reverse" (Müller, 1999, 37). "Yet the recent pension reform dynamics has shown that full or partial pension privatization can also be accomplished under democratic regimes. This suggests a need for fresh research into the political economy of pension reform to explain under which circumstances such a move is politically feasible" (Müller, 1999, 39). 


\section{THE LEGACY OF STATE SOCIALISM}

A mandatory pension system tied to employment was built up in Hungary under the socialist system. The statutory retirement age was set 60 for men and 55 for women. That was a rather low age limit in international comparison (Table 1), even if one takes into consideration that the difference of the actual retirement ages between the former socialist and the OECD countries is relatively small for men and significant only in the case of women (Augusztinovics, 1999b, 95).

Table 1

Retirement Age in International Comparison, 1991

\begin{tabular}{llc}
\hline & \multicolumn{2}{c}{ Statutory retirement age } \\
\cline { 2 - 3 } & Male & Female \\
\hline Hungary & 60 & 55 \\
\hline Other East-European countries & & 55 \\
\hline Bulgaria & 60 & 57 \\
Czechoslovakia & 60 & 60 \\
$\quad$ Poland & 65 & 55 \\
$\quad$ Romania & 60 & 60 \\
\hline Countries with similar GDP/capita & & 62 \\
$\quad$ Greece & 65 & $60^{\mathrm{a}}$ \\
$\quad$ Portugal & 65 & 55 \\
\hline Other European Community member countries & & 65 \\
\hline$\quad$ Germany & 65 & 65 \\
$\quad$ Italy & 60 & \\
$\quad$ Spain & 65 & 65 \\
\hline USA & & \\
\hline
\end{tabular}

${ }^{a}$ to be increased to 65 until 2004

Source: Andorka et al. (1993, 28).

The pension system consisted of one tier following the pay-as-you-go (PAYG) principle. The initial pension was a function of the number of years of employment and the magnitude of the income of the last years in employment. The ceiling on pensions was calculated as 75 percent of the labor income of the last three years (or the best three years out of the five last years) after 42 years of employment (Augusztinovics, 1993, 308). Pension benefits were financed from the state budget, expenditures were covered partly from taxes, partly from employee contributions. Employees paid a payroll tax that fluctuated between 3 and 15 percent of the labor income (Augusztinovics, 1993, 311). However, in the socialist system, pen- 
sion benefits were not directly linked to contributions: pension expenditure was not a function of contributions.

This state-run pension scheme with the rising number of employed and with longer and longer service period for employees, led to the increase of entry ratio (entry pension over last wage earned) between the 60s and 80s (Table 2).

Table 2

The System in Expansion, 1950-1980

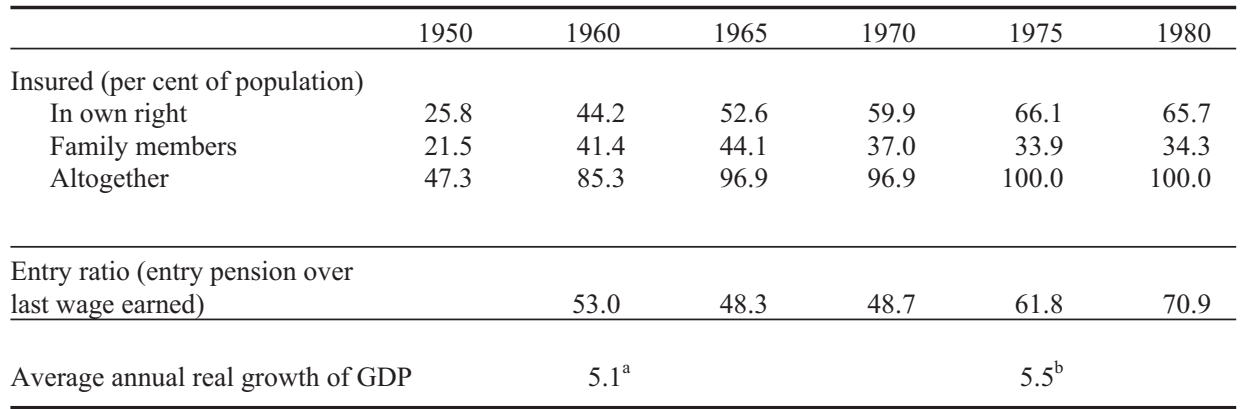

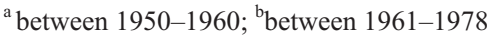

Source: Augusztinovics (1993, 309).

The socialist pension system based on the centralization of revenues was non-transparent and irrational, since the economic constraint to make extensive commitments for future pension expenditure remained invisible and ineffective for the government. On the other hand, it generated stability and provided relatively high level of pensions in relation to wages. The internal problems linked to financing and the maturing of the pension system remained concealed on the basis of a growing economy until the end of seventies.

In the eighties the Hungarian economy slowed down. Paying out quickly growing amounts of pensions from less quickly growing or even diminishing revenues created financial difficulties for the state budget. As a reaction the government started reducing the value of pensions. In 1982 the entry pension became degressive, in pension calculations higher wage brackets were taken into account at a lower percentage. With growing inflation nominal wages also grew, as a result higher and higher ratios of wages were calculated at a degressive rate. Also, the income of previous years was not valorized, as a consequence the average income of the last three years (that served as a basis for the pension calculation) sank below the pensioners' actual income at the moment of retirement. All this led to the decrease of entry ratio: the entry ratio of workers and employees dropped to 64 percent in 1990 (Augusztinovics, 1993, 310). Between 1975 and 1990 average pen- 
sion compensation lagged both behind the rise of prices and nominal wages. At the same time the lowest pensions were fully compensated. The preservation of a merely minimum subsistence level for the pensioners with lowest income was achieved by the reduction of higher pensions. As a result, pensions were compressed and lost contact with the years of contribution payments or wage differences. The average pension fell into the range of subsistence level (Augusztinovics, 1993, 311-312). Summing up, confronted with the growing financial difficulties of the pension system, in the name of solidarity the pension policy of the last socialist governments simply put the financial burden on the shoulders of pensioners.

“...'solidarity', a virtue often called for in issues of social security, has not been shown towards pensioners as a group but has been forced within the group" (Augusztinovics, 1993, 311).

\section{THE ECONOMICS OF PENSION REFORM}

\subsection{Piecemeal policy changes, 1990-1994}

\subsubsection{Financial dilemmas}

The transition from a centrally planned economic system to a market economy made unavoidable the strengthening of fiscal discipline for economic actors, the government included (Kornai, 1993b). Under the pressure of the transformational recession the introduction of hard budget constraint in financing pensions became even more urgent (for macroeconomic indicators see Table 3).

As early as 1989 the finance of social security was separated from the state budget, and a new Social Insurance Fund (SIF) was created. In 1992 the pension fund (Pension Insurance Fund - PIF) was separated from the Health Insurance Fund. However, these institutional changes in themselves could not achieve and guarantee the financial balance of the pension system. The PIF was running a deficit every year, although Hungarian economic policy was successful in keeping the ratio of pension expenditure to GDP at a more or less constant level, even under the circumstances of a falling GDP (see Tables 3 and 4).

The transformational recession made the attainment of sound financing in the pension system more difficult through its effects on the labor market. Growing fiscal discipline in the economy contributed to the sharp increase of unemployment. Between 1989 and 1995 the share of employed population dropped from 46.2 to 35.5 percent while more than 1.4 million jobs were lost (Csaba and Semjén, 1997, 5). The pension system served as an instrument easing the tension on the la- 
Table 3

Macroeconomic Trends, Hungary 1991-1999

\begin{tabular}{|c|c|c|c|c|c|}
\hline & Average 1981-90 & 1991 & 1992 & 1993 & 1994 \\
\hline Real GDP & 1.1 & -11.9 & -3.1 & -0.6 & 2.9 \\
\hline Unemployment & - & 6.2 & 15.3 & 19.1 & 16.9 \\
\hline Consumer prices & 10.7 & 34.8 & 22.8 & 22.4 & 18.8 \\
\hline $\begin{array}{l}\text { External current account } \\
\text { balance in percent of GDP }\end{array}$ & - & 1.2 & 0.9 & -10.9 & -9.7 \\
\hline $\begin{array}{l}\text { General government balance } \\
\text { in percent of GDP }\end{array}$ & - & -3.7 & -6.9 & -8.5 & -9.3 \\
\hline & 1995 & 1996 & 1997 & 1998 & 1999 \\
\hline Real GDP & 1.5 & 1.3 & 4.6 & 5.1 & 4.1 \\
\hline Unemployment & 16.3 & 16.5 & 15.9 & - & - \\
\hline Consumer prices & 28.3 & 23.5 & 18.3 & 14.3 & 10.0 \\
\hline $\begin{array}{l}\text { External current account } \\
\text { balance in percent of GDP }\end{array}$ & -5.7 & -3.8 & -2.2 & - & - \\
\hline $\begin{array}{l}\text { General government balance } \\
\text { in percent of GDP }\end{array}$ & -7.1 & -3.1 & -4.6 & - & - \\
\hline
\end{tabular}

Source: World Economic Outlook

Table 4

Hungary: Pension Funds as a \% of GDP

\begin{tabular}{lrrrr}
\hline & 1993 & 1994 & 1995 & 1996 \\
\hline Income & 9.2 & 8.8 & 9.0 & 8.2 \\
Expenditure & 9.4 & 9.4 & 9.3 & 8.6 \\
Deficit & -0.2 & -0.6 & -0.3 & -0.4 \\
Pension payments as a whole $^{\mathrm{a}}$ & 11.1 & 11.5 & 10.6 & $10.2^{\mathrm{b}}$ \\
\hline
\end{tabular}

a Including pension payments made outside the pension funds, such as social, war victims', sectorally specific (miners') pensions, early retirements, etc. $-{ }^{\mathrm{b}}$ Provisional.

Source: Lodahl $(1997,26)$

bor market by reducing labor supply via early retirement and disability pensions. As a result, after 1989 the system dependency ratio rose steeply. Since real pensions fell more sharply than real wages, the replacement ratio also declined after 1989, but this tendency was not strong enough to prevent the rise of the implicit contribution rate (Augusztinovics, 1999b, 94-95). The role assumed by the pension system in easing the tensions in the labor market created an obstacle to sound financing (Table 5). 
Table 5

Long-term Changes in the Characteristics of the Public Pension System during its Maturation Process

\begin{tabular}{|c|c|c|c|c|c|c|c|c|}
\hline Year & 1960 & 1965 & 1970 & 1975 & 1980 & 1985 & 1990 & 1994 \\
\hline $\begin{array}{l}\text { System dependency } \\
\text { ratio }^{\mathrm{a}}(\%)\end{array}$ & 13.4 & 23.7 & 27.7 & 34.4 & 35.8 & 40.8 & 46.1 & 71.8 \\
\hline $\begin{array}{l}\text { Replacement rate } \\
\text { (\% of net wages) }\end{array}$ & 32.4 & 32.3 & 34.4 & 42.2 & 55.5 & 56.2 & 66.1 & 60.8 \\
\hline $\begin{array}{l}\text { Implicit contribution } \\
\text { rate (\% of net wages) }\end{array}$ & 4.3 & 7.6 & 9.5 & 14.5 & 19.8 & 22.9 & 30.4 & 43.6 \\
\hline
\end{tabular}

${ }^{a}$ the ratio of pension recipients to contributors. In the table active population was used as a proxy for the number of contributors

Source: Csaba and Semjén $(1997,20)$.

While the system dependency ratio was deteriorating, after 1980 the oldage dependency ratio was almost stagnating: its growth was much slower (Table 6).

Table 6

Old-age Dependency Ratio, 1960-1999

\begin{tabular}{lc}
\hline Years & $\begin{array}{c}\text { Old-age dependency ratio } \\
(65-/ 15-64 \times 100)\end{array}$ \\
\hline 1960 & 13.6 \\
1970 & 17.0 \\
1980 & 20.9 \\
1990 & 20.9 \\
1991 & 20.2 \\
1992 & 20.4 \\
1993 & 20.4 \\
1994 & 20.6 \\
1995 & 20.7 \\
1996 & 20.9 \\
1997 & 21.0 \\
1998 & 21.2 \\
1999 & 21.3 \\
\hline
\end{tabular}

Source: Statistical Yearbook of Hungary $(1999,34)$.

The data above show that the financial difficulties of the pension system had to do less with population aging and more with the increase of the system dependency ratio: a diminishing number of contributors had to finance a growing number 
of pensioners. ${ }^{4}$ The two crucial variables deteriorating as a consequence of the transformational recession and keeping the pension system under pressure were the high system dependency ratio and the weak link between contributions and benefits.

Growing unemployment leads to the growth of early retirement and disability pensions, which leads to high system dependency ratio. Inflation is conducive to the devaluation and compression of pensions. It leads to a weaker link between contributions and benefits. A weak link between contributions and benefits limits the incentives to comply with the pension system and results in widespread contribution evasion. Reduced contributions increase further the system dependency ratio. As a consequence the pension system faces financial difficulties and ceteris paribus policymakers compress again pensions and also let pensions further devaluate. It weakens further the link between contributions and benefits, leading to higher system dependency ratios, and so on. In the absence of policy change the growing system dependency ratio and the weak link between contributions and benefits reinforce each other (Figure 1).

\subsubsection{Changes in pension policies}

Decision makers may choose among several policy alternatives for improving the high system dependency ratio. They may experiment either with parametric changes or with institutional reform or with the mix of the two. Parametric changes aim at increasing revenues and reducing expenditure in the pension system. It also may comprise several policy measures, as follows:

\section{Parametric changes}

Increasing revenues

(1) increasing the number of those who pay contributions

(2) increasing the retirement age

(3) increasing the contribution rate.

Reducing expenditure

(1) diminishing the replacement ratio (either through diminishing the size of starting pensions in relation to average wages and/or through avoiding to preserve the value of existing pensions);

(2) increasing the retirement age;

4 “...in a changing economic environment, system dependency can be much more strongly affected by employment opportunities than by pure demographic trends... The future of pension systems thus seems to be in the hands of developments in the labour market" (Augusztinovics, 1999, 96). 
(3) restricting the number of recipients through tightening the eligibility criteria;

(4) lengthening the minimum contribution period and limiting the use of noncontributory periods in calculating the benefit.

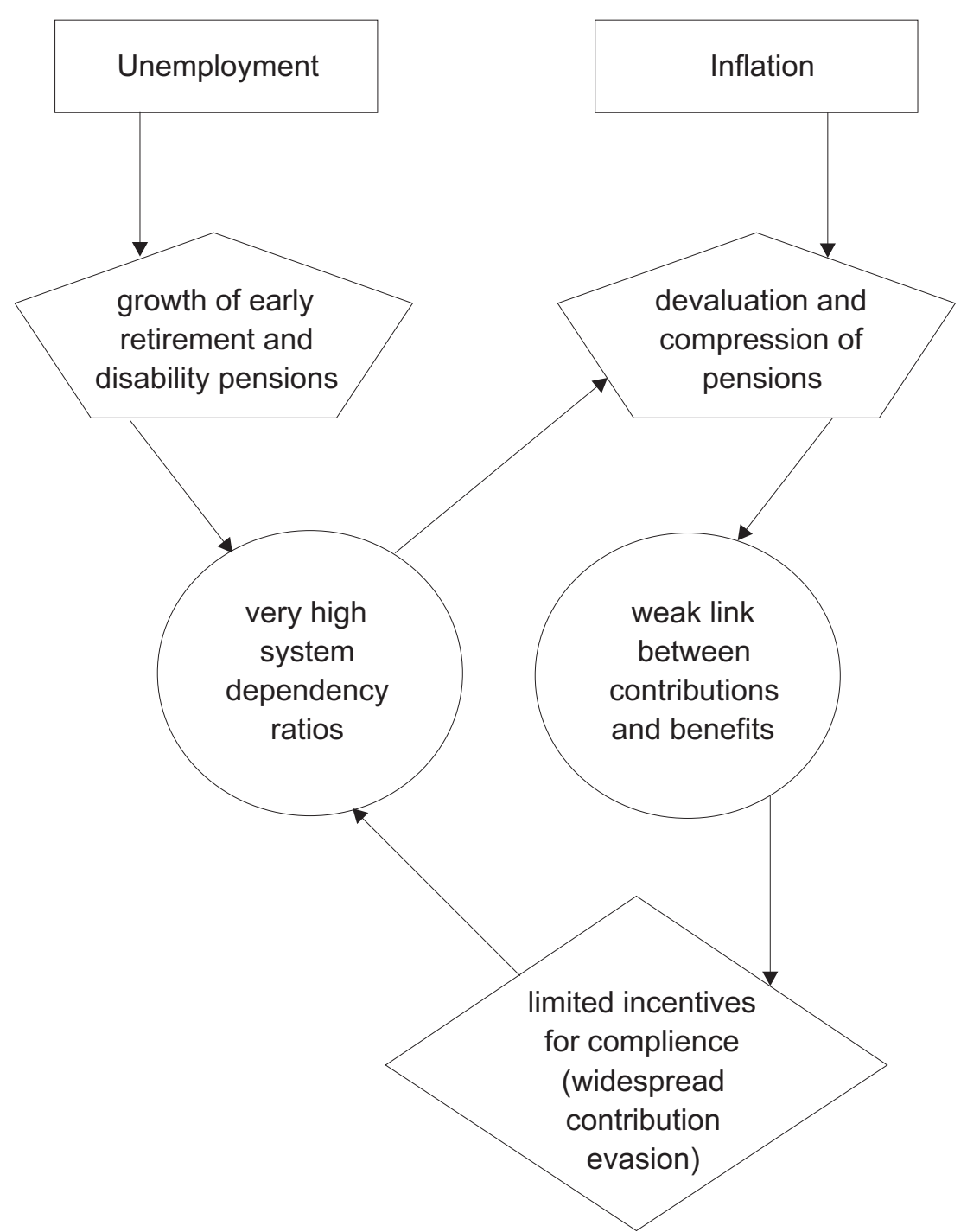

Figure 1. The impact of the transformational recession on the pension system 
Not all of these measures were taken by the Hungarian government between 1990 and 1994. Raising the contribution rate can be done only within certain limitations, due to its negative effect on economic incentives and competitiveness. Since the contribution rate was already high in Hungary, this option was not viable. Increasing the retirement age would have been an effective measure for easing the financial pressure on the pension system, but the Antall government (in office between 1990 and 1994) refrained from doing it for political reasons: raising the retirement age is very unpopular. Increasing the contribution base and tightening eligibility criteria were also not seriously considered at that time, for similar reasons as in the case of raising the retirement age. However, something had to be done about the fiscal problems, so the government used the tool of decreasing the replacement ratio (the ratio of pensions to net wages). This also was a painful policy but not for the employees, only for the pensioners. Also, inflation could partly be blamed for this.

After 1990 in Hungary, new (entry) pensions were made lower than the average pension. New pensions pushed the level of average pensions downward (Augusztinovics, 1999a,130). The reduction of the replacement ratio was achieved by the introduction of a new pension formula in 1991. This formula did three things:

1. Avoided valorizing fully those earlier wages that served as a basis for the pension calculation.

2. Took into account the wages in a degressive way. After 10 service years the pension was 33 percent of the wage taken into account in pension calculations, between 10 and 25 service years, every year added 2 percentage points to the pension value, after 25 years the pension reached 63 percent of the wage. Then up to 32 service years every year added 1 percentage point to the pension, after this the growth of pension fell to an annual 0.5 percent. Due to the effects of inflation and the abruptly changing wage dynamics that destorted the pension base (1) and (2) together led to the drop of entry pensions in relation to the average wage.

3. Less than full indexation of earlier pensions to gross wages also contributed to the reduction of the replacement rate (Palacios and Rocha, 1998, 185; Simonovits, 1999, 213-214). The characteristics of the pension system before the institutional reform are summarized in Table 7.

The option of institutional reform was considered by the Antall government, but was not implemented. In theory the necessity of institutional reform of the existing PAYG system was accepted. In 1991, the Hungarian Parliament passed a resolution that remained within the confines of the PAYG pension regime, but contemplated an important restructuring of the PAYG pillar by separating the solidarity function and the insurance function of the pension system into two distinct tiers, and also proposed the introduction of a voluntary private pillar. The 60/1991 
Table 7

Major Trends in the Pension System of Hungary, 1990-1996

\begin{tabular}{|c|c|}
\hline & Pension System in Hungary \\
\hline Pension expenditure over GDP & Broadly constant (at about 10 percent of GDP) \\
\hline Number of pensions & $\begin{array}{l}\text { Rising rapidly ( } 20 \text { percent during } 1989-1995) \text {, reflecting the } \\
\text { sharp increase in disability pensions, but also early retirement }\end{array}$ \\
\hline Average pension in real terms & $\begin{array}{l}\text { Sharp drop in real terms ( } 25 \text { percent in real terms between } 1990 \\
\text { and } 1995 \text {, more than the decline in real wages) due to } \\
\text { less-than-full price indexation, and fall in the real value of pen- } \\
\text { sion at entry }\end{array}$ \\
\hline Pension revenues over GDP & $\begin{array}{l}\text { Dropping rapidly because of base erosion, in the presence of high } \\
\text { contribution rates }\end{array}$ \\
\hline Number of contributors & Declining \\
\hline Contribution rate & $\begin{array}{l}\text { Broadly constant at very high levels ( } 35 \text { percent); declining in } \\
1997 \text { ( } 31 \text { percent) }\end{array}$ \\
\hline Notional PAYG rinancial balance & $\begin{array}{l}\text { Notional PAYG balance deficit deteriorating by about } 2 \text { percent- } \\
\text { age points of GDP during 1991-1995 }\end{array}$ \\
\hline
\end{tabular}

Source: Cangiano et al. $(1998,12)$.

resolution of the Parliament foresaw a three-tier pension system: (1) a flat-rate universal pension, provided by the government to every citizen; (2) a labor pension related to life-time earnings and mandatory contributions, paid in by employers and employees; and (3) a voluntary supplementary insurance scheme.

In 1993 the setting up of voluntary private pension funds was allowed, the government supported the voluntary private schemes with generous tax exemptions (up to a ceiling of 200 thousand HUF, 50 percent of the payments in the private pension funds could be written off from the personal income tax). However, with this exception the comprehensive institutional reform was substituted by austerity measures that served the aim of easing the financial tensions within the pension system. In the first period of the postsocialist transition, following the practice of the $80 \mathrm{~s}$, the burden of inappropriate financing of the pension system had to be borne by the majority of pensioners themselves.

\subsection{Institutional reform, 1995-1998}

\subsubsection{Policy alternatives}

March 1995 meant a break with the historical continuity of the Hungarian economic policy: under the pressure of a threatening economic and financial crisis, the Hungarian government introduced an austerity program and gave its support to a liberally minded reform initiative that also led to the 1997 pension reform. 
Pension policy had to face the dilemma that postponing institutional reforms does not make it possible to avoid unpopular measures aiming at cutting existing entitlements and provision levels. An institutional reform did not make these measures superfluous. The idea was that by changing the incentive structure an institutional reform may also be able to discover and mobilize new resources. There emerged a more or less general consensus about the necessity of institutional reform.

The emerging consensus ${ }^{5}$ about the necessity of an institutional pension reform rested on the following considerations:

1. The pension system has to face demographic problems: the aging of population will exert financial pressures on the pension system around 2010 and then around 2040, when the generations of two earlier baby booms (around 1950 and 1970) will go on retirement. On the other hand, the demographic situation at present opens up a window of opportunity for reforms.

2 . The vicious circle between worsening system dependency ratios and weaker and weaker links between contributions and benefits must be broken by reestablishing the link between contributions and benefits. It creates individual incentives for paying contributions. The rules and the functioning of the pension system must become transparent. This requires the separation of the solidarity function from the insurance function within the pension system.

3. Support should be given to a voluntary private pension scheme.

How to implement these goals? There was no consensus in answering the questions of institution building. Two contradicting reform projects emerged, let me call them social versus liberal ${ }^{6}$ reform alternatives.

\subsubsection{Pension debates}

The representatives of the social reform version argued for keeping the PAYG scheme as the main pillar of the pension system. They proposed a three-tier pension system: (1) a flat-rate basic pension determined in the percentage of the average wage or minimum wage and financed from taxes; (2) a contributions-related labor pension financed from contributions; (3) a voluntary private pension scheme. The main supporters of the PAYG system were the Ministry of Welfare, the PIF and the unions.

5 In the description of this consensus I rely on Augusztinovics (1996).

6 I use the adjective "liberal" the way it is used in Europe and not in the United States, referring to market-oriented attitudes as opposed to those biased toward state intervention (the term "liberal" in the United States would mean "conservative"). 
The advocates of the liberal reform version proposed the privatization and the marketization of the pension system. They planned a different three-tier pension system: (1) a basic pension financed from mandatory contributions (PAYG pillar); (2) a privately funded pension scheme financed from mandatory contributions (mandatory privately funded pillar); (3) a voluntary private pension scheme. For those who cannot finance a pension these three pillars would be supplemented by (4) a means-tested social assistance financed from the state budget providing a minimum subsistence. The main supporter of the mandatory privately funded system was the Ministry of Finance (the two reform proposals are summarized in Table 8).

Table 8

Pension Reform Proposals in Hungary, 1996

\begin{tabular}{|c|c|c|}
\hline Reform projects & Liberal & Social \\
\hline Proponents & Ministry of Finance & $\begin{array}{l}\text { Pension Insurance Fund (trade unions), } \\
\text { Ministry of Welfare }\end{array}$ \\
\hline \multicolumn{3}{|l|}{ First tier } \\
\hline Type & basic pension for contributors & Universal flat rate minimum pension \\
\hline Financing & $\begin{array}{l}\text { PAYG; } \\
\text { contributions to be paid only } \\
\text { by employers }\end{array}$ & $\begin{array}{l}\text { PAYG; } \\
\text { Tax-financed }\end{array}$ \\
\hline Level & 25 percent of average net wage & $60-70$ percent of subsistence minimum \\
\hline \multicolumn{3}{|l|}{ Second tier } \\
\hline $\begin{array}{l}\text { Type } \\
\text { Financing }\end{array}$ & $\begin{array}{l}\text { mandatory private, defined contribution } \\
\text { FF; }\end{array}$ & $\begin{array}{l}\text { Mandatory public, earnings-related } \\
\text { PAYG; notional defined contributions } \\
\text { with prefunding }\end{array}$ \\
\hline Level & $\begin{array}{l}\text { Contributions to be paid } \\
\text { only by employees } \\
\text { Depending on investment returns } \\
\text { and on entire earnings history }\end{array}$ & $\begin{array}{l}\text { Contributions shared between } \\
\text { employers and employees } \\
\text { Depending on entire earnings } \\
\text { history }\end{array}$ \\
\hline
\end{tabular}

Source: Müller (1999, 75) (modified)

The reform debate in justifying the respective reform proposals focused on the following subjects: (1) social values; (2) linking contributions to benefits; (3) reducing risks; (4) stimulating savings and investment; (5) costs and revenues.

1. Social values. The advocates of the social version emphasized the value of solidarity, the importance of social integration and the intrinsic redistributive character of the PAYG scheme. They criticized the liberal pension reform for vio- 
lating the value of equity through neglecting the interests and social rights of those in need, its bias toward the well-to-do social strata and its vulnerability toward the narrow financial interests of capital market actors. The advocates of the liberal pension reform stressed the importance of the value of individual responsibility and self-reliance. ${ }^{7}$ They thought that the multi-tier pension system served better the values of solidarity and equity than a single-tier PAYG system because it could separate the different logic of equity and insurance that were hopelessly mixed in the PAYG system.

2. Linking contributions to benefits. The supporters of the privatization and marketization of the pension system criticized the single PAYG system because, as a result of uniting the principles of solidarity and insurance in one scheme it weakens the link between contributions and benefits. They argued that a pension system relying on a privately funded scheme could reestablish a close relationship between contributions and benefits. As a consequence the privately funded pension system might increase savings, stimulate investments, create incentives for contributing to the pension scheme, and increase old-age security (Ferge, 1998 , 12). The advocates of the funded system claimed that the PAYG scheme in aging societies could be sustained only by imposing ever-higher costs on society; these costs would cripple recovery and growth and lead to induce such widespread evasion that the system would gradually collapse. While introducing a compulsory fully funded 'second pillar' with benefits tightly linked to contributions, evasion could be reduced (Nelson, 1998,15-16). The advocates of the PAYG system said that a reformed PAYG scheme was sustainable. The necessary reforms should include the raising of retirement age, the tightening of the links between contributions and benefits, and the establishment of predictable and equitable methods for adjusting pensions to changes in prices and economic circumstances. In their opinion the same economic incentives can be created for individual pensioners as in a private scheme by introducing individual accounts based on a point-system into the PAYG pillar (Augusztinovics and Martos, 1996, 141-146; 156-157).

3. Reducing risks. The advocates of the PAYG system pointed out that in a privately funded system the investment risk of pension assets had to be borne by the insured, because high inflation may erode the accumulated pension capital in real terms. The supporters of the privately funded system pointed out that the PAYG scheme was open to political manipulation, the government would not be able to

These values were also given a great emphasis in Kornai (1996c). On the similarities and differences between Kornai's argument and the position of the Ministry of Finance (Urbán, 1998). 
guarantee the real value of pensions, and it would give back to the pensioners only a part of the value of their contributions. The value of pensions paid to pensioners depends, both in the PAYG and in the funded system, on the government of the economy; therefore, the privately funded scheme is no more risky than the PAYG scheme (Interview with Ádám Gere, 1997).

4. Stimulating savings and investment. The advocates of the liberal pension reform argued that the PAYG system contributions financed current pensions, consequently they were converted into consumption, while in the funded system money paid in would be converted into investments that would generate a higher rate of economic growth (Interview with Ádám Gere, 1997). The advocates of the social pension reform did not accept the investment-argument. They said that the investment originating from that part of mandatory contributions that would flow into the private pension funds, money invested in capital markets, could not generate real investments, because the missing amount of contributions in the PAYG pillar had to be made up for financing the pensions of those staying in the first pillar. Deficits can be avoided by loans given to the PAYG scheme and financed from the capital market: there would be no net saving and investment to be used (Augusztinovics, 1996, 32). More precisely, there will be a net gain only if the interest on the loans to be serviced is below the gains received on the investments financed by contributions. On the other hand, the reform of the PAYG system can stabilize the system even in the long run, surpluses can also be accumulated and invested within a PAYG system, and present gains can be accumulated and used for financing future deficits. That was highly improbable, answered the supporters of the liberal reform: the PAYG system could not accumulate surpluses, because politicians would not resist the temptation to use the surplus for current purposes, or the PIF would not be able to resist the demands to raise pensions. The privately funded system with its individual capital accounts is more safely separated from political influence, and after a transitional period relying on the private incentives it generates it will be able to increase savings and investments.

5. Costs and revenues. The advocates of the PAYG system made the reproach that the high transaction costs for administering the private funds would reduce future benefits. Due to the transition from the single-pillar system to the multi-pillar one there are high transition costs that place a double burden on the present generations of contributors. In the opinion of the supporters of the privately funded system, assuming that there is no population growth and the age structure of the population is constant, the revenue of the PAYG system depends on the growth rate of average income, while the revenue of the funded system depends on the return on capital. If the return on capital is higher than the growth rate of wages, the funded system is more advantageous than the PAYG system. In the last 20-25 years that was the case, said the advocates of the funded system (Csontos, 1997, 33); how- 
ever, this argument conflates two different problems, say the critics. Two different pension systems can be fairly compared only if both systems are fully mature, or if a country starts a new pension system without antecedents. Neither situation is the case in Hungary, where the gradual transformation of an existing system is at stake (Augusztinovics, 1999b, 101).

\subsubsection{The 1997 pension reform}

The reform debates were followed by the pension reform in 1997. The government decided to introduce a mixed multi-pillar system with a mandatory privately funded tier, that is the government finally accepted the liberal version of the pension reform.

An important element of the pension reform was already introduced in 1996: the statutory retirement age was elevated from 60 for men, and 55 for women to a unified 62 years. For women this new age limit becomes effective in 2009, for men in 2000 (Simonovits, 1999, 216). Raising the retirement age was an unavoidable step in the reform process. However, the students of pension reform emphasize, that this measure improves the financial situation of the pension system only at the expense of other subsystems of social policy. Ceteris paribus, due to the effect of the rise of retirement age on the labor market, the older generations remain longer in employment and may prevent the young generations from entering the labor market, or the elderly people may become unemployed instead of becoming pensioners. All this may result in extra financial burden for the unemployment insurance and/or social assistance (Augusztinovics and Martos, 1996, 155; Augusztinovics, 1996, 29).

The bill on the comprehensive reform of the pension system passed by the Parliament in 1997, set up a mandatory funded pillar, but preserved the prominence of the earnings-related PAYG pillar, by reducing the share of the funded scheme in terms of contributions to a quarter of total mandatory pensions funds. This reform was coupled by the modification of the PAYG pillar: the earlier increase in the retirement age to 62 in 1996 was now supplemented by the increase in minimum years of service for early retirement and a change in the pension index-formula (linking pensions to gross wages and consumer prices equally). Since 1992 the value of pensions has been linked to average wages, but because real wages were falling, the real value of pensions was also falling. However, on the basis of a newly growing economy, wages started increasing in 1997, while the rate of inflation was falling. Linking the value of pensions partly to prices and not completely to wages slowed down the increase of pensions. Consequently, these measures were important in creating a sound financial basis of the PAYG pillar by increas- 
ing contributions and limiting pension expenditures. The new pension formula within the first pillar eliminated degression. Every service year was given the same value: instead of net wages gross wages will serve as the basis of calculation, providing 1.65 percent for those who remain exclusively within the PAYG system, but only 1.22 percent for those who joined the second pillar (Simonovits, 1999, 218-219). Those who opted also for the second, privately funded pillar will lose 25 percent of their previously accrued pension rights (Augusztinovics, 1999b, 101). Minimum service years were not changed, they remained at 20 years, but eligibility criteria were tightened. Noncontributory years for students and maternity leave were reduced (Cangiano, Cottarelli and Cubeddu, 1998, 25-28). Changes in the first PAYG pillar are summarized in Table 9.

\section{Table 9}

Status of reform of the PAYG system in Hungary

\begin{tabular}{ll}
\hline Increase in retirement age & $\begin{array}{l}\text { Reform of PAYG } \\
\text { (women) }\end{array}$ \\
Indexation rules & $\begin{array}{l}\text { Changed from net wages to a weighted average of gross nominal wages } \\
\text { and prices. Starting in } 2001 \text { the weight will be 50/50 (Swiss formula) }\end{array}$ \\
Benefit formula & $\begin{array}{l}\text { Lower coefficients applied to workers' gross wage history. Previously } \\
\text { higher coefficients to workers' net wages }\end{array}$ \\
Eligibility criteria & $\begin{array}{l}40 \text { years of contributions and } 59 \text { years of age for early retirement. Reduc- } \\
\text { tion of noncontributory years for students and maternity leave }\end{array}$ \\
Taxation & Contributions exempt, benefits taxed under the personal income tax \\
\hline
\end{tabular}

a introduced already in 1996

Source: Cangiano et al. (1998, 25)

The changes in the first PAYG tier were supplemented by the introduction of a second fully funded mandatory private tier. The characteristics of the second tier are shown in Table 10.

By establishing the second pillar of a mandatory funded scheme the new pension system had to face a difficult period of transition from a single PAYG system. The mixed system was mandatory for new entrants in the labor force as of July 1 , 1998. Those being employed were given a choice to move to the mixed system, but guarantees within the new system were provided only to workers who would participate in the second pillar for at least 15 years. Workers were given two years to exercise their rights to switch to the new system - until August 31, 1999. Workers could also return to the reformed PAYG until September 2000 (Palacios and Rocha, 1998, 195). 
Table 10

Main Features of Mandatory Fully Funded Pillar in Hungary

\begin{tabular}{ll}
\hline Financing and tax treatment & $\begin{array}{l}\text { Features of Mandatory FF Pillar } \\
\text { plying a loss of revenues for the PAYG scheme of about } 0.8-1.3 \text { percent } \\
\text { of GDP in the early years of the reform, depending on the number of } \\
\text { workers opting out of the new system. The tax treatment will be a modi- } \\
\text { fied EET system (pension contributions and investment income from pen- } \\
\text { sion funds exempt; pension benefits taxed under personal income tax) by } \\
\text { allowing a } 25 \text { percent tax credit on mandatory employee contributions } \\
\text { Most of the investments will be initially in government's papers. Limits } \\
\text { will be relaxed once the pension funds reach a certain level of assets. Pen- } \\
\text { sion funds will not be allowed to invest in foreign securities in 1998. This } \\
\text { limit would be progressively raised to } 30 \text { percent over a five-year period } \\
\text { Private mutual pension funds managed by their members } \\
\text { Type of funds } \\
\text { There is a unified public supervisory body for mandatory and voluntary } \\
\text { pension funds, financed by a share of pension funds' premia } \\
\text { There are two layers of protection. First, individuals participating in the } \\
\text { second pillar will be guaranteed annuities equal to } 25 \text { percent of the value } \\
\text { of the first pillar pension. Second, there is a relative rate of return guaran- } \\
\text { tee loosely connected with the individual guarantee and backed up by the } \\
\text { resources of the Guarantee Fund. The Supervisory authority has discretion } \\
\text { in setting the range of investment returns in a given period }\end{array}$ \\
\hline
\end{tabular}

Source: Cangiano et al. (1998, 34).

The contributions paid into the PAYG scheme make out 30 percent of gross wages, 21 percent is paid by employers and 9 percent is paid by employees. In the new mixed system 22 percent of gross wages goes to the PAYG pillar (21 percent paid by employers and 1 percent paid by employees) and 8 percent paid by employees goes into to the second pillar. There is a two year transitional period for the rearrangement of contributions: the employee contribution to the second pillar was 6 percent in 1998, and the Act on Pensions foresaw a one percent rise in 1999 and in $2000 .{ }^{8}$ The overall contribution rate would remain unchanged as employer rates were reduced (Palacios and Rocha, 1998, 196 and 214). Employee contributions were capped at twice the average wage, while employer contributions were not capped.

Since the introduction of a new privately funded second pillar leads to the channeling of parts of the contributions from the first pillar into the second one, the

8 However, the new government elected in 1998 decided to freeze the contribution rate to the privately funded system at the 1998 level. 
most important financial problem of the transition period is to substitute the missing contributions in the PAYG scheme (due to the high level of contribution rate raising it was out of question). It must be facilitated by the government. At least part of the transition costs needs to be financed from the state budget. The Ministry of Finance estimated the annual burden of the budget at around $0.8-1.3$ percent of GDP (Palacios and Rocha, 1998, 199).

The mandatory contributions to the second pillar are being placed into privately managed pension funds. The two pillars are supplemented by a voluntary system of private insurance and a government financed social assistance, paying means-tested minimum pensions for those in need.

"The Hungarian decision to shift intragenerational redistribution outside the traditional PAYG scheme but retain a significant role for the public pension scheme effectively resulted in a four-pillar system: a 'zero' pillar consisting of a means-tested income guarantee for the old, financed from general taxes; a first pillar, consisting of an earnings-related PAYG, financed entirely from contributions; a second pillar, mandatory, private and fully funded; and a voluntary pillar" (Palacios and Rocha, 1998, 211).

\section{THE POLITICS OF PENSION REFORM}

\subsection{Piecemeal policy changes, 1990-1994}

The conservative Antall government that came to power after the elections in 1990 carried out the separation of the Pension Insurance Fund from the Health Insurance Fund between 1991 and 1992. The government also formulated its comprehensive reform project that was mirrored in the resolution of the Parliament in 1991 (this resolution was discussed earlier in this paper). However, the government refrained from the implementation of the reform. The delay may have to do with the negative political consequences of a radical reform.

Politicians interested in maximizing votes are very careful about reforms that would combine growing financial burdens with changing or even diminishing social services for large segments of the population. A radical turn in the pension policy was considered to be very unpopular and would create political dissatisfaction. Changing the pension system radically (for instance raising the retirement age: calculating pensions on the basis of lifetime earnings, not just the last few years: introducing a flat-rate minimum pension, etc.) would have escalated the growing unpopularity of the current government. The positive results of the reform would not be felt for at least a generation, so it is not a surprise that the first 
postsocialist government (under the circumstances of economic recession that resulted in a declining standard of living for the majority of the population), was inclined to postpone the comprehensive reform of social policy. The politicians of the ruling coalition refrained from a reform that would have inflicted pain to an important segment of voters in the present and promised positive results only in a distant future. It leads us to the conclusion that "the benefit of crises" thesis (Drazen and Grilli, 1993, 598; Müller, 1999, 46-47) does not always work, that is, it must be specified. The deep economic crisis generated by the transformational recession did not force the Antall government to carry out the pension reform, to the contrary, the negative social effects of the transition were cushioned by the pension system. The Hungarian government postponed the institutional pension reform for political reasons, consequently burdening the pensioners themselves with this decision.

Katharina Müller explains the postponement of reform, by the political resistance that is reinforced by the large blame-generating potential of an institutional reform, which remains within the confines of the PAYG system. Reforms like this are politically sensitive: they easily allow the identification of individual losses, and are perceived as a mere cutback of acquired entitlements - without anything in exchange. Furthermore, the political unattractiveness of 'PAYG-only' reforms is exacerbated by a credibility problem of policymakers, who cannot make a convincing commitment that the proposed reform is a lasting one (Müller, 1999, 161). The argument about the sensitiveness of the reform of the single PAYG system is important. However, it is difficult to find a direct causal link between political resistance against the pension reform and the postponement of the reform. Probably, the lack of initiative on the part of the government was more important in postponing institutional reforms than the strength of political resistance. In other words, the refrainment of the government from pension reform was not a result of strong resistance: resistance represented by interest organizations was weak, because these organizations were weak. The Hungarian government avoided the reform in spite of the fact that there was no strong, well-organized opposition against it. ${ }^{9}$

Nevertheless, abstaining from radical reforms did not mean that things could remain the same. For economic reasons the Antall government was forced to reduce the real value of pensions, and diminish the pension differences within the system. As a consequence, first, the government contributed to the weakening of the insurance principle within the pension regime. Second, the burden of adapta-

9 Charlton, McKinnon and Konopielko $(1998,1417)$ explains the politicians' failure to introduce radical changes in the pension system with "...the need to maintain retirement pensions as a form of unemployment insurance...". 
tion was shifted onto the pensioners. This process added to growing impoverishment among the pensioners. ${ }^{10}$

The government's policy of letting the value of pensions erode had contributed to the loss of confidence in the PAYG scheme in the population.

Postponing important but unpopular reforms in the domain of social policy could not save the conservative government, after the elections of 1994 a new socialist-liberal coalition government was formed. Up until March 1995 the Horn government also refrained from radical reforms in the sphere of state expenditures, maintaining a long-term continuity of gradualism in economic policy making, that was rooted in the reform-socialism of the pre-nineties. ${ }^{11}$

\subsection{Reform bargains after 1994}

In 1994 important macroeconomic indicators of the Hungarian economy deteriorated (Table 3). The twin deficits of the balance of payment, and the state budget reached a critical value. The current deficit of the balance of payments reached 9.6 percent of GDP and the domestic indebtedness of the general government in 1994 reached 83.2 percent of GDP (Kornai, 1996b, 150 and 159). The Hungarian economy that had to manage a relatively high level of foreign indebtedness (external debt increased from USD 21 billion in 1990 to almost 30 billion in 1994) was risking to lose the confidence of foreign investors and the international financial community. The IMF had already earlier canceled its agreement with Hungary. If the government wanted to avoid a financial crisis it had to make efforts to regain the shattered confidence of investors and international financial institutions. This situation led to the introduction of an - in Hungarian terms radical and drastic - austerity package. The austerity package was initiated by the newly appointed Minister of Finance, Lajos Bokros and backed up by the President of the National Bank of Hungary, György Surányi. The austerity program was introduced by the Horn government without previous negotiations with interest organizations, or the parliamentary fraction of socialist MPs, or socialist party activists.

Although the austerity program contained a set of short-term objectives, Bokros was determined to initiate long-term reforms in the fiscal system, and also

${ }^{10}$ In 1992 out of the 2.7 million pensioners 1 million (that makes $10 \%$ of the Hungarian population) lived under the minimum standard of living. Between 1989 and 1992 even the real value of the minimum pension decreased by $21 \%$ (Ferge, 1993, 271).

11 See Kornai 1996a. 
in the field of social policy, first of all in the pension system and in health care. ${ }^{12}$ Under Bokros the initiative of social policy reforms was taken by the Ministry of Finance. Other domestic actors like the Ministry of Welfare, the Pension Insurance Fund, the Health Insurance Fund, and the unions, could only react to the propositions of the Ministry of Finance. Although Bokros resigned in a year, reforms were carried on by his successor, Péter Medgyessy, and the Ministry of Finance preserved its pivotal role in the reform process. This important change in the balance of power between the Ministry of Finance and the Ministry of Welfare that finally decided the course of pension reform was the result of a political decision: top policy makers, first of all Socialist Prime Minister Gyula Horn, gave the green light to the Ministry of Finance. Leading politicians feared losing the trust of foreign investors, and the international financial community, resulting in disaster for the Hungarian economy. The increased power of the Ministry of Finance was caused by the threat of economic crisis, and was not deliberately set up for the purpose of the pension reform. In that sense the pension reform was an externality created by a crisis situation that, following a political decision, made it possible for the Ministry of Finance to combine short term austerity measures aimed at macroeconomic stabilization, with the long term institutional reform of the pension system. ${ }^{13}$

12 "The March 1995 stabilization law represents the first attempt at a comprehensive reform of welfare policy, as opposed to piecemeal measures. It also represents a milestone in the political history of Hungary, as the governing coalition broke the pact of not playing the 'social card' that had been tacitly agreed between the major parties in 1989" (Dethier and Saphiro, 1998, 457).

13 This explanation deviates from that given by Müller (1999). She attributes the enhanced power of the Ministry of Finance to the economic pressure of the constant deficit of the Pension Insurance Fund that gives an opportunity for the Ministry of Finance to intervene. "...it was the local PAYG system's dependence on budgetary subsidies ... that granted the Finance Ministry an important stake in reforming old-age security. Hence, 'the benefit of crises' hypothesis can, for the Hungarian and Polish cases, be interpreted in such a way that the financial difficulties of both the general government budget and the public old-age scheme can be seen to have resulted in a significant change of the local constellation of actors" (Müller, 1999, 169). However, the deficit of the PIF in Hungary was not very high in comparison to the deficit of the Health Insurance Fund. First, this deficit was constantly present after 1990 (Table 4), but the Ministry of Finance was given a chance to determine the discourse on the pension reform only after 1994. Second, although the deficit was much higher in the Health Insurance Fund than in the Pension Insurance Fund, the Ministry of Finance was not able to carry out a comprehensive reform in this sector. All this means that there may be a relation between the role of the Ministry of Finance in social security reforms and the deficits of the funds of social insurance, but this connection is not direct and not causal. The causal link is mediated by the role and intentions of political actors in this process. 
In June 1995, the Committee on state finance reform passed a resolution on the pension reform that followed the guidelines of the 60/1991 Parliamentary Resolution, and focused on the possible reforms within the existing PAYG system. However, this resolution was not discussed by the government. A few weeks later the Committee on state finance reform handed in a proposal for the government on the pension reform advocating the implementation of a mandatory privately funded pillar. This was followed by the proposal of the Minister of Finance. This proposal foresaw the comprehensive privatization of the pension system. Minister of Finance, Lajos Bokros was in favor of a one hundred percent privately funded system, although the technocrats and specialists in the Ministry of Finance suggested a fifty percent privately funded mandatory pension scheme (Bossányi, 1997, 14).

This proposal was opposed by the Ministry of Welfare, the PIF and the unions. In the bargaining process that followed the announcement of the reform plan, the Ministry of Finance could make a deal with the Ministry of Welfare by reducing the share of the funded pillar to thirty percent in the reform proposal (Ferge, 1998, 10). This compromise was still unacceptable both for the unions and the PIF. The unions controlled the governance board of the PIF, and the PIF was afraid of losing power in administering pensions.

"...pension reforms that channeled a sizable and growing fraction of pension contributions away from the system managed by the Pension Insurance Fund and into individual, privately managed accounts clearly threatened MSZOSZ (the largest trade union) power and financial interests" (Nelson, 1998, 23).

However, the government was able to get the consent of unions in the Council of Interest Reconciliation (CIR - the Hungarian tripartite organization) on the basis of a package deal. The PIF and the HIF were organized on the principle of self-governance: the members of the Boards nominated by the unions were earlier elected by the citizens. Now, the government initiated the change of the voting rules in the Parliament and made it possible for the unions to nominate their representatives without elections onto the Boards. The change served the interests of the biggest union (MSZOSZ) that was to be given 7 of 15 labor seats in the Boards. In exchange, the representative of the MSZOSZ voted for the pension reform in the CIR (Nelson, 1998, 24). Following these bargains the Parliament ratified the bill on pension reform in the summer of 1997.

The 1997 bill on pension reform was seen by all the actors as a successful reform. The government considered the bill as a historical breakthrough in the direction of a privately funded pension reform. The opponents of the reform (Ministry of Welfare, PIF and the unions) could be satisfied with the compromise they had achieved, after all, the weight of the funded pillar was reduced to 25 percent and an earnings-related PAYG system was maintained. The government also skillfully avoided hurting the interests of present pensioners and those presently em- 
ployed with the introduction of the reform. First, employees were given a choice whether to stay entirely in the PAYG or move into the second pillar, second, the introduction of the reform was connected to a promise to increase pensions. ${ }^{14}$ Finally, although the pension reform contained a series of painful measures that cut current and future expenditures in the PAYG pillar, linking these cuts to the introduction of a new privately funded pillar made the whole package more acceptable for a great number of voters.

"... under the mixed package deal the difficult task of reforming the PAYG system is bundled up with the introduction of a mandatory private tier. This 'obfuscation strategy'... lowers the visibility of the envisaged cutbacks, drawing public attention to the granting of individualized, visible ownership claims, i.e. individual pension accounts with private pension funds, to large segments of the population" (Müller, 1999, 161) ${ }^{15}$.

The new pension system proved to be a great political success, if success was to be measured in the number of those employees who opted for entering the second pillar. By the end of 1999 more than two million people, 49 percent of the active population opted for the mixed pension system instead of the pure PAYG system in Hungary. This number has significantly exceeded the number predicted by prior calculations (HFSA, 2000, 5). This showed that the state-run PAYG had lost the confidence of citizens. People do not believe that the government will keep its promises in the future and will preserve the value of their future pensions. They trust much more the impersonal forces of markets in this respect - it is a trust that is rooted in the inexperience of employees with private pension schemes and in the ignorance about the real costs and benefits of the transition. ${ }^{16}$

\subsection{Conclusion}

The "benefit of crises" hypothesis can only be applied to the history of pension reform in Hungary if it is complemented by the role of other factors. Although Hungary was hard hit by an economic crisis in the form of the transformational recession in the first half of the $90 \mathrm{~s}$, the pension reform was not introduced, it was rather

14 Pensioners were promised to receive a 6 percent real increase in their pensions, effective at the beginning of 1998 (Nelson, 1998, 21). It is another case that after the 1998 elections the Orbán government did not keep the promises made by the Horn government.

15 Similar argument was formulated by Simonovits $(1999,221)$ and Urbán $(1998,392)$.

16 Németh attributes the popular success of the privately funded pillar to the cuts in the provisions of the PAYG pillar: people compare the revenues coming from their contributions to the first and the second pillar, and if they find that the expected revenues are higher in the second pillar (due to the cuts in the first pillar), they will place their money in the second pillar (Németh, 1998, 31).

Acta Oeconomica $51(2000 / 2001)$ 
postponed. The economic crisis, instead of generating a pressure to introduce pension reform served opposite tendencies, it provided incentives for postponing the reform, since the pension system could be instrumental in cushioning the changes in the labor market related to growing unemployment. On the other hand, due to the financial problems stemming from the role the pension system played in easing the hardships in the labor market, the tension on policy makers to introduce reforms in the pension system was growing, since the worsening of the system dependency ratio made the financing of the pension system more and more difficult. In that respect the impact of the economic crisis still pushed political actors toward the reform in the longer run.

The "benefit of crises" explanation works for the breakthrough in the Hungarian pension reform taking place after 1995. However, it was not the deficit of the pension system and also not the external indebtedness of the country in itself that changed the balance of power of the actors, which was a necessary condition of the reform. Rather, it was the 1995 economic crisis threatening the loss of confidence of foreign investors that made politicians give the initiative to the Ministry of Finance for coping with this crisis. The window of opportunity was opened up by this decision. This decision was not aimed at the introduction of the pension reform in the first place, but led to a change in the balance of power that was a precondition of the pension reform.

The introduction of a mixed pension system can be attributed to the following factors: (1) economic constraints; (2) changing balance of power among actors; (3) the pattern of reform bargains; (4) the paradigm shift in reform strategy; (5) the impact of path dependence; (6) the role of the World Bank.

1. Economic constraints. When policy makers felt they were running into the economic constraints stemming from an ensuing economic crisis, they let the Ministry of Finance carry out an austerity program and an institutional pension reform. The agenda of the pension reform became linked to the policy measures coping with the economic crisis. That made the pension reform work.

2. Changing balance of power. The Ministry of Finance took the initiative and redefined the discourse on pension reform advocating a mixed pension system with a mandatory privately funded second tier. The Ministry of Welfare and the unions had not enough power to push through the social pension reform against the liberal one.

3. Pattern of reform bargains. Although the Ministry of Finance originally insisted on the introduction of the mandatory FF tier and on the diminished role of the PAYG scheme, the final reform outcome was the result of a compromise that saved the pivotal role of the PAYG pillar and reduced the role of the mandatory FF pillar. The compromise was a necessary precondition for implementing the pension reform. 
4. Paradigm shift in reform strategy. ${ }^{17}$ Although the pension reform contained a series of painful measures that cut current and future expenditure in the PAYG pillar, linking these cuts to the introduction of a new privately funded pillar made the whole package more acceptable for a great number of voters.

5. Impact of path dependency. On the one hand, path dependency was important in the postponement of the reform, since it generated popular expectations about pension expenditure, making the necessary cuts in pension provision more difficult. On the other hand, path dependency had also a positive effect on the reform, since on the basis of their previous experience with the PAYG system people lost confidence in the PAYG system, and gave support to the pension reform aimed at the implementation of a mandatory FF pillar. It is an effect of path dependency that people trust more the impersonal forces of the market than the promises of the government - it is a trust that is also reinforced by the inexperience of would-be pensioners with fully funded private pension schemes.

6. The role of the World Bank. The pension reform was the outcome of the interaction of domestic actors and reflected their values and interests. However, the World Bank played an important role in shaping the pension reform agenda. This role requires further elaboration, which is provided in the next section of the paper.

\section{THE ROLE OF THE WORLD BANK IN THE HUNGARIAN PENSION REFORM}

\subsection{International Financial Institutions versus domestic actors}

International Financial Institutions (IFIs) have certainly influenced domestic policy makers in their decisions about the course of policies and institutional reforms in the postsocialist transition. This influence would not have been possible if the different actors had not shared a certain set of general values about the desirable direction of policy measures. On the other hand, domestic actors and the IFIs did not have to have identical reform plans, and in practice they really did not, which would seem obvious, since IFIs and domestic actors faced different constraints and followed different values in their actions. IFIs tried to implement the universal institutions of a market economy in the postsocialist countries under the hard economic constraint of their budgets. Domestic politicians tried to build up a market economy that fit the historical circumstances of their country under the political constraint of keeping or losing power. The actual political choices had to be made

17 On this concept see Holzmann $(2000,18)$ and Müller $(1999,161)$. 
by domestic actors, but IFIs determined the content of these decisions through a process of bargaining with national governments. These bargains were also learning processes that could change the proposed policy content on both sides. ${ }^{18}$

The World Bank could be an influential player in the postsocialist transition of the last ten years because governments in Eastern Europe badly needed money but also much more than that. The policy advice and technical expertise provided by the Washington twins proved to be even more important than the amount of money spent in the region. ${ }^{19}$ Advice and expertise supplied by the IMF and the World Bank were formulated in universalistic technical terms but were obviously loaded with a set of coherent values emerging on the basis of Anglo-Saxon modernization. The policy propositions of the IMF and the World Bank aimed at stabilization and institution building were deduced from the so called Washington consensus. ${ }^{20}$ Is the Washington consensus different from the course of European economic policies? Not really. The principles of economic integration in Europe, especially after the decision to introduce the EMU linked to the Maastricht convergence criteria, did not constitute an alternative to the economic policy proposals of the IMF and the World Bank. Tight monetary policy, prudent fiscal policy, an independent national bank, economic openness, marketization and privatization, etc., these were policy proposals that were endorsed by the representatives of the EU as well.

However, things may have looked different in the case of social policy proposals. The IMF and the World Bank deduced social policy options from a broader set of economic objectives. They made the point that accession to the EU could only be achieved by Hungary if she was able to maintain a higher level of economic

18 "The economic transformation has been a learning process for both the reforming countries and the assisting IFIs" (Zecchini, 1995, 137).

19 "Ironically, it is more plausible to locate the Bank's comparative advantage in assisting development in the presence of weaknesses and distortions in member countries' domestic political processes than in overcoming the international capital-market imperfections that so concerned its founders. If so, this suggests that, much more than its lending operations per se, the Bank's role as policy adviser and institution-builder has been the key to its impact on economic development" (Gavin and Rodrik, 1995, 331). "Bank money always came with ideas and advice attached" (Gavin and Rodrik, 1995, 333).

20 The main points of the Washington consensus are the following: 1. Fiscal discipline. 2. Changing the priorities of public expenditure: reallocating resources to basic health care, basic schooling, infrastructure. 3. Tax reform: widening the tax base and lowering tax rates. 4. Financial liberalization with market clearing interest rates. 5. Exchange rate policy: exchange rates should facilitate exports. 6. Liberalization of foreign trade. 7. Foreign direct investment: to create identical conditions for the competing domestic and foreign firms. 8. Privatization. 9. Deregulation: maintaining free entry to markets. 10. Property rights: to guarantee the security of property. For a discussion of these points see Lányi (1997). 
growth than the EU average. Looking at the task of the accession to the EU, the IMF and the World Bank have emphasized the importance of fiscal discipline in attaining the desired rate of economic growth. A sustainable high rate of economic growth needs a stable economic environment as its condition: low inflation and fiscal discipline. Fiscal discipline is a crucial problem in the postsocialist transition, since the revenue-collecting capacity of the government has been substantially weakened, while the need for social expenditure, especially under the circumstances of the transformational recession, has increased. ${ }^{21}$ To maintain fiscal discipline one has to reform the fiscal sphere. Social policy reforms should serve this purpose: these reforms are seen as vital in creating a stable economic environment that is conducive to economic growth. ${ }^{22}$ In other words, social policy reforms should ease the fiscal crisis of the postsocialist state, these reforms should create a social policy regime that targets scarce economic resources on the poor.

"With this broadening of focus, the interrelationships between economic and social issues have also increasingly been recognized. The experience has shown the need for protecting vulnerable groups during the adjustment period by constructing well-targeted social safety nets and by safeguarding their access to basic public services, such as primary health and education. These measures would also serve to enhance the political sustainability of economic reforms." (Social Dimensions, 1995, 5)

This policy proposal is rather paradoxical: in the name of successful accession to the EU it is advocating a social policy regime that in its philosophy is much closer to the residual welfare logic of the American welfare state than to that of the more solidaristic welfare regimes of Europe. But is it not the same logic that is coming out of the endeavors of EU member states to maintain an economic policy

21 "Has the country not chosen spending programs - particularly in the social protection areas - that are too generous for its own good? Does it not risk, in attempting to fund these programs with such large amount of resources, stifling the chances of successfully catching up with the rest of Europe within the next generation?" (Barbone and Polastri, 1998, 170).

22 "Given the desirability of accelerating economic growth and converging rapidly toward EU income levels, it is asked under what conditions high growth is compatible with achieving the targets of the Maastricht Treaty. Can Hungary implement a credible medium-term program to converge toward Maastricht without imposing excessive social hardships? The answer is yes provided that irreversible public sector reforms are introduced - but meeting the public-debt criterion will require putting a stronger emphasis on fiscal consolidation than what is implied by the Treaty" (Dethier and Orlowski, 1998, 95). “... to avoid stifling economic growth with excessive levels of taxation, priority should continue to be assigned to sustainable reductions in public outlays. These require profound reforms of major spending programs, and a redefinition of the role of the state in many critical areas, particularly those related to social protection" (Barbone and Polastri, 1998, 169). 
that is in tune with the Maastricht convergence criteria? It is true that European welfare regimes are also undergoing changes that are closely linked to the problems of economic competitiveness and to the maintenance of the new European monetary regime. However, taking policy measures like cuts in state expenditure and introducing reforms like partial privatization and marketization of social provisions still do not seem to challenge the underlying common philosophy of the different European welfare state ${ }^{23}$ as opposed to that of the American welfare state. Does it mean for the postsocialist countries that following the "neoliberal" IMF and World Bank propositions on social policy reforms in the name of assisting the accession process, puts them to a path that is leading away from Europe? I am going to use the case of pension reform in Hungary in order to be able to answer this question.

\subsection{The role of the World Bank between 1990 and 1994}

The World Bank (and the IMF too) had examined the social policy expenditure in Hungary already in 1990-1991. The World Bank report found that Hungary spent a higher share of GDP to social expenditure than the share that could be justified by the income level of the country in comparison to the high-income market economies. The report proposed that reforms should narrow entitlements, and target expenditures. Individuals should take higher responsibility for their own welfare, and the role of the private sector in social provisions should be enhanced. The reform proposal focused on the task of restoring economic incentives and creating financial stability for the pension system by reducing expenditures. This purpose may be achieved by gradually raising the age of retirement from 60 for men and 55 for women to a unified 65 . The World Bank also proposed to change the pension formula that would link indexation of pensions with calculating pensions on the basis of life-time earnings. In the long run the World Bank proposed a two-tier pension system. The first tier should serve as a minimum pension with fixed payments, the second tier should provide earnings-related pensions (A Világbank, 1992, 16-19 and 70-75). At that time all these propositions had clearly taken for granted the framework of the existing PAYG system administered by the government and later by the PIF. Policy recommendations did not go beyond it, and did not formulate the goal of privatizing the pension system. The 60/1991 resolution of the Hungarian Parliament was in accordance with the reform proposals of the

23 It is important to talk about European welfare states in the plural. A European Welfare State does not exist and there are arguments that there will never be one (Streeck, 1996). 
World Bank. However, the avoidance of a pension reform between 1990 and 1994 indicates that IFIs do not have the capacity to enforce reforms when domestic actors think they should not implement them. ${ }^{24}$

\subsection{World Bank pension reform proposals after 1994}

The situation changed in 1995 when, fearing a devastating collapse of the economy, the Hungarian government opted for radical policy measures. The political determinedness to carry out a painful stabilization, reinforced the role and influence of the Ministry of Finance who also took the initiative in the field of social policy. All of this opened up the domain of reforms to the strategic influence of the World Bank that had close ties to the Ministry of Finance, and provided advice to politicians and technocrats, who shared the values and the vision behind the technical solutions proposed by this international financial institution. ${ }^{25}$

By 1995 the World Bank was well prepared to initiate a pension reform for Hungary and the other postsocialist countries, a reform that was different from its earlier propositions made in 1991. The new concept of the pension reform was published by the economists of the World Bank in 1994 (Averting, 1994). The reform proposals of the World Bank also appeared in the 1995 country study on Hungary (Magyarország, 1995).

In the views of the World Bank the pension system needed reforms to restore its financial viability by extending the basis of contribution and reducing pension expenditure. The kernel of the reform was to create a pension scheme that would provide incentives for economic actors to save part of their income and to contribute to the financing of the pension system. The implementation of this goal needed first, the reform of the PAYG pillar, and second, the implementation of a privately funded pillar (Magyarország, 1995, 27-28).

The pension reform proposal of the World Bank did not foresee the full privatization of the existing pension scheme. As the country study stated, there were

24 "Inherent limits to the IMFs and the World Bank's power to impose policy are evident since they lacked the means to discourage Hungarian governments from adopting populist measures and socially motivated growth-promoting policies at those times when systemic and other, broader conditions for the sustainability of growth were clearly nonexistent." "...being a watchdog of balance of payment disequilibria, the Fund is ill-suited to enforce structural reforms. When Fund assistance is needed, immediate, often administrative, steps to improve the balance of payments are necessary. When improvement occurs and reserves are built up, only enlightenment and persuasion remain and the Fund has no leverage over an unwilling government" (Csaba, 1995, 230-231).

25 Müller (1999, 75-76, 88, 168-172).

Acta Oeconomica 51 (2000/2001) 
strong arguments in favor of the participation of the government in the pension system. First, in every society there are people who do not finance their pensions from the market either because they do not save money voluntarily or because their market income is too low for this. Second, market-based pension systems may experience market failures due to information problems, inflation and other causes. So, the World Bank study said, the critical question was not whether the government participated in the pension system, but to what extent the government should do this (Magyarország, 1995, 31).

Any pension system should satisfy two conflicting goals, first, it should create a social safety net for elderly people, second, it should pay pensions in relation to former salaries and contributions. The single pillar system cannot simultaneously satisfy these contradicting objectives, cannot fulfill the goal of social redistribution and the goal of generating the necessary savings at the same time, the World Bank country report said (Magyarország, 1995, 31). Therefore, runs the argument, the pension reform should aim at the implementation of a multi-pillar scheme. The first pillar should pay a general minimum pension on the basis of citizenship, the second pillar should pay earnings-related pensions. According to the World Bank proposition the first pillar could be a reformed PAYG scheme, while the second pillar should be a mandatory privately financed funded scheme that would generate the right incentives by creating a transparency between contributions and benefits. This transparency cannot be achieved in a PAYG system that cannot avoid the compression of payments and the limitation of contributions because of its vulnerability to political pressures, says the World Bank country report. The privately funded pillar has the advantage that it insulates the pension scheme from government intervention. According to the World Bank proposal the share of the reformed PAYG in the new pensions should be between 30 and 50 percent, that of the private pillar should be about 30-35 percent (Magyarország, 1995, 38-39 and 41). That was the reform project the World Bank proposed to Hungarian policy makers in the reform process.

\subsection{The role of the World Bank in the 1997 pension reform}

The history of the pension reform shows that the World Bank had a clear role by setting the agenda for the pension reform; its proposals about the course of the reform had an impact on the reform objectives worked out in the Ministry of Finance that proved to be the strongest player in the period of the formulation of reform alternatives. However, the pension reform following the guidelines of the World Bank could be achieved only because a minimum consensus of domestic actors could be generated for the reform proposals in the process of bargaining 
that led to important compromises. ${ }^{26}$ The reform implemented did not reduce the role of the PAYG to the provision of a basic or minimum pension: it is an important deviation from the original World Bank reform propositions and contributed to the preservation of the European character of the new Hungarian pension regime. ${ }^{27}$

Although the outcome of all the efforts to change radically the pension regime in Hungary led to partial changes in the financial logic of the pension schemes, the economists of the World Bank welcome the reform as a breakthrough in privatizing the social security subsystem of the country.

"Political compromises have weakened the original reform concept and it could be argued that the Hungarian reform does not go far enough in raising national savings and in reducing distortionary payroll taxes. Although these may be valid criticisms, it should be noted that the improvement relative to the no-reform scenario is still very significant - the reform would succeed in transforming pension deficits averaging around 3 percent of GDP into pension surpluses of more than 1 percent of GDP (public and private balance combined) by the end of the next decade, while promoting the development of capital markets" (Palacios and Rocha, 1998, 210).

The pension reform was also praised because it allowed simultaneously a reduction in government spending, the promotion of private saving, and improvements in competitiveness, thereby contributing to an increase in the growth potential of the economy.

The success of the World Bank in having an impact on the reforms implemented was possible only because powerful domestic actors shared the values and the attitudes represented by the IFI. The case of the Hungarian pension reform did not give justice to those criticisms that state that the World Bank applies identical remedies of a market-oriented, free-enterprise philosophy irrespective of a country's circumstances, in a doctrinaire way, ignoring the views of governments

26 “...the international financial community (including but going well beyond the World Bank and the IMF) contributed powerfully to the evolution of thinking regarding pension reform options, and to the political decision that early action was imperative. Both timing and broad shape of reform were influenced by outside forces. But the more specific design details were outcomes of the analysis and political judgement of the reformers themselves, and of their negotiation and compromises within their governments and with interest groups, watchdog institutions, and legislatures" (Nelson, 1998, 19; Müller, 1999).

27 In Katharina Müller's words: while Poland and Hungary “...did resort to partial pension privatization, following Latin American role models, the reform efforts of these countries remained well within the boundaries of the Bismarck-Beveridgean pension traditions" (Müller, 1999, 52). 
of the respective countries. ${ }^{28}$ It is true that the World Bank policy proposals on the pension reform were cast in the framework of neoliberal ideas, but the Bank showed great flexibility in applying general ideas to specific circumstances. Also, domestic actors had their freedom in deviating from, and compromising on the reform proposals in the framework of a domestic political bargaining process. $^{29}$

Why did domestic actors follow the policy proposals of the World Bank? Comparing pension reforms in Poland, Hungary, and the Czech Republic, Katharina Müller argues that the World Bank was able to perform as a major external actor in the pension reform in Hungary and Poland as opposed to the Czech Republic because of the existence of an accumulated high external debt in the former two countries. When the recommendations of the IMF and the World Bank "....are disregarded by local governments, alternative sources of market financing can usually not be relied upon. Hence it can be expected that the more severe the external debt problem in a given country is, the greater the leverage of the World Bank will be" (Müller, 1999, 54). The World Bank's leverage “... in Hungary and Poland results largely from both countries' high external debt burden ... In the Central-Eastern European pension reform arena, the Bank did not exert its influence through the 'classical' channel, through conditionalities, but first and foremost as an agenda shifter in the local debate, via its local campaign for Latin American-style reforms" (Müller, 1999, 169).

However, the Hungarian case of pension reform does not confirm a direct or single relationship between the country's indebtedness and the implementation of the pension reform along the guidelines of the World Bank. It was not the extent of indebtedness that opened up the political domain for a pension reform advocating a second private tier, but the financial crisis in 1995, that put the government under growing pressure. The goverment was afraid of losing the confidence of the international financial community, beacause this loss would have endangered the

28 A list of criticisms can be found in Krueger (1998).

29 "Greater World Bank technical assistance does not produce a larger private, funded pillar. Two factors seem to explain this. First, the World Bank does not always advocate a larger funded pillar and gives a variety of options within the multipillar system... Second, the World Bank is not the only source of pension reform ideas ... This suggests that World Bank influence depends on its relations to key veto and proposal actors. When it gives advice to a single, dominant proposal actor, the World Bank can be extraordinarily effective. However, when multiple proposal actors are involved in the policy process, the World Bank can only advocate its position in government fora, support a chosen proposal actor through technical assistance, and accept final outcomes of reform that depend on domestic political processes. One clear commonality is that the World Bank will generally support reforms that have some funded component, but this may come in a wide variety of forms" (Orenstein, 2000, 39). 
economic strategy of the Hungarian governments to rely on foreign direct investment in generating economic resources for economic growth. The fear from a devastating economic crisis made politicians seriously consider painful economic policy changes and institutional reforms in the pension system. True, foreign indebtedness played an important part in this process, because this strategy also implied the readiness to service the foreign debts of the country in order to remain an attractive target for investments. However that constraint in itself, being there for a long period of time, does not explain that sudden shift in the balance of power within the government that made it possible to launch a market-oriented pension reform in and after 1995. What is more, the pension reform in Hungary took place under the circumstances of a diminishing extent of foreign indebtedness in and after 1995.

The financial crisis that threatened to turn away foreign investors from Hungary, strengthened the positions of those who urged the imposition of financial discipline and market-oriented reforms also in the sphere of social welfare. The pension reform was pushed through by those domestic actors who shared the economic philosophy of the World Bank and were able to win over politicians to their ideas under the given circumstances that threatened with a deepening crisis and the loss of foreign monetary resources. If the technocrats at the top of, and within, the Ministry of Finance had not identified themselves with the neoliberal values represented also by the World Bank, the IFI would have had no influence on the course of the Hungarian pension reform. The economic philosophy of the Ministry of Finance can be understood in terms of identities but also in terms of interests.

Under the pressure of legitimation deficit, arising from the gap between given expectations about proper pension levels and the diminishing capacity of the government to fulfill these expectations, the government may find it attractive to withdraw from the financing of the pension system and diminish the legitimation deficit by shifting part of the financing to impersonal market mechanisms. Privatization of the pension system does exactly this and may help the government to reduce the overload on the budget and be seen as the proper policy, when the government feels it is unable to match its present and future financial commitments. ${ }^{30}$ This policy course fits the neoliberal values and the two may reinforce each other.

30 "...the privatization of at least portions of existing pension systems, at once removing revenue and expenditure responsibilities from the states has become, at least in principle, a fiscally attractive policy option to government élites increasingly anxious to alleviate burgeoning budgetary deficits by any means possible" (Charlton, McKinnon and Konopielko, 1998, 1415). 


\subsection{Conclusion}

The assistance of the IFIs has contributed to the process that has put Hungary to a trajectory that may lead to, and not away from, the EU. In the field of macroeconomic policy the IMF and the World Bank insisted on imposing a financial discipline on the major economic actors, urged a consequent anti-inflationary monetary policy and stressed the importance of private investments against excessive government expenditure. These economic goals were in correspondence with the economic policy objectives of the EU, and were reinforced by the new monetary regime of EMU.

The economic requirements of the EMU put the European welfare states under financial pressure. Governments in Europe face the difficult task of cutting back social expenditure and at the same time maintaining the solidaristic character of their welfare states. The postsocialist states are confronted with the same task but for different reasons. In the process of the postsocialist transition, governments have to cope with the legacy of the communist welfare state that has generated relatively high expectations in the population and relatively high commitments for the government to fulfill these expectations. The government must also create a sound financial basis for social expenditures under and after the circumstances of the transformational recession. To achieve a sustainable growth in the postsocialist countries is a precondition for the accession to the EU. To implement reforms in the domain of social welfare is a precondition for achieving a sustainable growth. This way the social policy reforms proposed by the IMF and the World Bank are instrumental for the accession process to the EU. It may be the case that the underlying general philosophy of the reforms proposed by the IFIs in Washington is tilted toward the residual welfare state, but as the history of the pension reform in Hungary has proved, the specific reform propositions and the final outcome of the reform bargains between domestic actors have remained within the framework of the more solidaristic European welfare states. The new mixed pension system has preserved the prominent role of the solidaristic PAYG pillar. The extent of privatization of the pension scheme in Hungary has not exceeded the extent that cannot be tolerated by the member states of the EU.

\section{Acknowledgement}

I am grateful for the intellectual and financial support provided by the Institut für Wirtschaftsforschung Halle in writing this paper. I would like to thank the members of the research group Mittel- und Osteuropa at IWH and especially Hubert Gabrisch and Johannes Stephan for their comments on the draft of the paper. I also thank an anonymous referee for his or her valuable comments. 


\section{REFERENCES}

Averting the Old Age Crisis. Policies to Protect the Old and Promote Growth (1994): A World Bank Policy Research Report. Published for the World Bank, Oxford: Oxford University Press.

A Világbank szociálpolitikai jelentése Magyarországról (The social policy report of the World Bank on Hungary) (1992): Szociálpolitikai Értesitö, No. 2: 3-228.

Andorka, R., Kondratas, A. and Tóth, I. Gy. (1993): A jóléti rendszer átalakulása Magyarországon: felépitése, kezdeti reformjai és javaslatok (The transformation of the welfare system in Hungary: its structure, initial reforms and proposals). Magyar Nemzetközi Kék Szalag Bizottság 3. sz. gazdaságpolitikai tanulmány (Hungarian International Blue Ribbon Committee, essay on economic policy, No. 3).

Augusztinovics, M. (1993): The social security crisis in Hungary. In: Székely, I. P. and Newbery, D. M. G. (eds): Hungary: An Economy in Transition. Cambridge: Cambridge University Press, 296-320.

Augusztinovics, M. (1996): Miröl szól a nyugdíjvita (What is the pension debate about?). INFO-Társadalomtudomány, No. 37: 27-32.

Augusztinovics, M. (1999a): A nyugdíjprobléma demográfiai és gazdasági alapjai (The demografic and economic bases of the pension problem). Demográfia, 42 (1-2): 120-132.

Augusztinovics, M. (1999b). Pension systems and reforms in countries in transition. Economic Survey of Europe 3(3), Geneva: UN Economic Commission for Europe, 89-113.

Augusztinovics, M. and Martos, B. (1996): Pension reform: Calculations and conclusions. Acta Oeconomica, 48 (1-2): 119-160.

Barbone, Luca and Polastri, Rossana (1998): Hungary's public finances in an international context. In: Bokros, L. and Dethier, J. J. (eds): Public Finance Reform during the Transition. The Experience of Hungary. Washington, D.C.: The World Bank, 155-173.

Bossányi, K. (1997): A gazdaságtól függ, hogy hány nyertes és vesztes lesz. Beszélgetés Győrfi Istvánnal, a nyugdíjreform leköszönt miniszteri biztosával (It depends on the economy, how many winners and losers there will be. Interview with former ministerial commissioner, István Győrfi). Népszabadság, September 16, 14.

Cangiano, M., Cottarelli, C. and Cubeddu, L. (1998): Pension developments and reforms in transition economies. IMF Working Paper, No. 151, October, 1-47.

Charlton, R., McKinnon, R. and Konopielko, L. (1998): Pension reform, privatisation and restructuring in the transition: Unfinished business or inappropriate agendas? Europe-Asia Studies, 50 (8): 1413-1446.

Csaba, L. (1995): Hungary and the IMF: The experience of a cordial discord. Journal of Comparative Economics, 20 (2): 211-234.

Csaba, L. and Semjén, A. (1997): Welfare Institutions and the Transition: In the Search of Efficiency and Equity. Discussion Papers, No. 47, Budapest: Institute of Economics, Hungarian Academy of Sciences.

Csontos, L. (1997): Nyugdíjfinanszírozási rendszerek (Financing pension systems). Beszélö, 2 (1): $30-36$.

Dethier, J. J. and Orlowski, V. (1998): Long-term effects of fiscal adjustment. In: Bokros, L. and Dethier, J. J. (eds): Public Finance Reform during the Transition. The Experience of Hungary. Washington, D.C.: The World Bank, 47-58.

Dethier, J. J. and Saphiro, T. (1998): Constitutional rights and the reform of social entitlements. In: Bokros, L. and Dethier, J. J. (eds): Public Finance Reform during the Transition. The Experience of Hungary. Washington, D.C.: The World Bank, 447-476. 
Drazen, A. and Grilli, V. (1993): The benefit of crises for economic reforms. American Economic Review, 83 (3): 598-607.

Ferge, Zs. (1998): Szociális törvénykezés a rendszerváltás óta (Social policy legislation since the systemic change). Esély, No. 3: 3-23.

Ferge, Zs. (1993): Magyar szociálpolitika, 1992 (Hungarian social policy, 1992). In: Kurtán, S., Sándor, P. and Vass, L. (eds): Magyarország Politikai Évkönyve (Political Yearbook of Hungary). Budapest: Demokrácia Kutatások Magyar Központja Alapítvány, 268-276.

Gavin, M. and Rodrik, D. (1995): The World Bank in historical perspective. American Economic Review Papers and Proceedings, 85 (2): 329-334.

Holzmann, R. (2000): The World Bank approach to pension reform. International Social Security Review, 53 (1): 11-34.

Hungarian Financial Supervisory Authority (HFSA) (2000): Review of the Various Funds. 1994-1999, April.

Interview with Ádám Gere (1997): Magyar Narancs, 9 (3): 23.

Kornai, J. (1993a): Transformational recession: A general phenomenon examined through the example of Hungary's development. Economie Appliquée, 46 (2): 181-227.

Kornai, J. (1993b): The evolution of financial discipline under the postsocialist system. Kyklos, 46 (3): 315-336.

Kornai, J. (1996a): Paying the Bill for Goulash Communism. Harvard University and Collegium Budapest Institute for Advanced Study, Discussion Paper No. 1748, Harvard Institute of Economic Research, Harvard University, Cambridge, Mass.

Kornai, J. (1996b): Vergődés és remény (Struggle and hope). Budapest: Közgazdasági és Jogi Könyvkiadó.

Kornai, J. (1996c): Az állampolgár és az állam. A jóléti rendszer reformja (The citizen and the state. The reform of the welfare system). Mozgó Világ, 22 (2): 33-45.

Krueger, A. O. (1998): Whither the World Bank and the IMF? Journal of Economic Literature, 36 (4): 1983-2020.

Lányi, K. (1997): A globális konvergencia változatai: Washington és Maastricht, I-II (Variations on global convergence: Washington and Maastricht). Külgazdaság, 41 (11): 5-29, and (12): 4-19.

Lodahl, M. (1997): Pensions in the transformation process: the situation in Hungary, the Czech Republic and Slovakia. Economic Bulletin DIW, 34 (12): 21-28.

Magyarország. Szerkezetváltás és tartós növekedés (Hungary: structural reforms for sustainable growth). (1995): Világbank Országtanulmány (A World Bank country study). Washington, D.C.: World Bank.

Müller, K. (1999): The Political Economy of Pension Reform in Central-Eastern Europe. Cheltteham, Northampton, MA: Edward Elgar.

Nelson, J. M. (1998): The Politics of Pension and Health Care Delivery Reforms in Hungary and Poland. Collegium Budapest, Institute for Advanced Study, Discussion Paper Series, Discussion Paper No. 52.

Németh, Gy. (1998): A nyugdíjreform makroökonomiája (The macroeconomics of pension reform). Esély, No. 6: 19-43.

Offe, C. (1990): Contradictions of the Welfare State. Cambridge, MA: The MIT Press.

Orenstein, M. A. (2000): How Politics and Institutions Affect Pension Reform in Three Postcommunist Countries. Policy Research Working Paper 2310, The World Bank Development Research Group, Poverty and Human Resources.

Palacios, R. and Rocha, R. (1998): The Hungarian pension system in transition. In: Bokros, L. and Dethier, J. J. (eds): Public Finance Reform during the Transition. The Experience of Hungary. Washington, D.C.: The World Bank, 177-219. 
Simonovits, A. (1999): The new Hungarian pension system and its problem. In: Müller, K., Ryll, A. and Wagener, H. J. (eds): Transformation of Social Security: Pensions in Central-Eastern Europe. Heidelberg: Physic, 211-230.

Social Dimensions of the IMF's Policy Dialogue (1995): Washington, D.C.: International Monetary Fund.

Statistical Yearbook of Hungary (1999): Budapest: Központi Statisztikai Hivatal.

Streeck, W. (1996): Neo-voluntarism: A new European social policy regime? In: Marks, G., Scharpf, F. W. and Schmitter, Ph. C. (eds): Governance in the European Union. London: Sage, 64-94.

Urbán, L. (1998): Nyugdíjreform-vita Magyarországon (The debate on pension reform in Hungary). In: Gács, J. and Köllő, J. (eds): A “túlzott központositástól” az átmenet stratégiájáig. Tanulmányok Kornai Jánosnak (From "overcentralization" to the strategy of transition. Essays for János Kornai). Budapest: Közgazdasági és Jogi Könyvkiadó, 385-396.

Zecchini, S. (1995): The role of international financial institutions in the transition process. Journal of Comparative Economics, 20 (2): 116-138. 